\title{
Determinants of Financing Decisions of SMEs: Evidence from Hotel Industry
}

\author{
Andreas Mueller ${ }^{1} \&$ Luca Sensini $^{2}$ \\ ${ }^{1}$ Business Economics Laboratory, HUB, Berlin, Germany \\ ${ }^{2}$ Department of Management and Innovation Systems (DISA/MIS), University of Salerno, Italy \\ Correspondence: Luca Sensini, Department of Management and Innovation Systems (DISA/MIS), University of \\ Salerno, Italy. E-mail: 1sensini@unisa.it
}

Received: January 18, 2021

doi:10.5539/ijbm.v16n3p117

\author{
Accepted: February 15, 2021 \\ Online Published: February 27, 2021 \\ URL: https://doi.org/10.5539/ijbm.v16n3p117
}

\begin{abstract}
This paper intends to analyze the determinants of hotel SMEs' capital structure, using the theoretical reference framework and the main indicators suggested by the Trade-off and the Pecking Order theories. The financial information was collected from the AIDA database and concerned a sample of 145 Italian hotel SMEs. To evaluate the capital structure, we used a set of dependent (Total Debt, Long Term Debt and Short-Term Debt) and independent (Profitability, Assets Tangibility, Growth, Size and Age) variables consolidated in the literature. After testing the least-squares model (POLS) and the fixed effects model (FEM), we chose to use the FEM model for our analysis, as it had a greater explanatory capacity. The results showed that the variables considered have a different weight in explaining hotel companies' capital structure. In particular, profitability, assets tangibility and size were the most significant variables, while the growth and age showed less relevance.
\end{abstract}

Keywords: capital structure, financing decisions, leverage, hotel industry, SMEs

\section{Introduction}

Tourism is considered one of the largest and most dynamic industries globally (Wang, 2015; Weiermair, 2006), contributing significantly to employment rates and economic growth. Moreover, tourism produces a multiplier effect because of numerous interactions established with other industries (Macchiavelli, 2001). In 2017, in Italy, $5.5 \%$ of GDP and 6.5 of employment (equal to almost 1.5 million jobs) were attributable directly to tourism (WTTC, 2018). Moreover, if we also estimate the indirect and induced contribution, which includes the supply of goods and services activated by businesses in the tourism sectors and the consumption of tourism workers, the overall impact of tourism on GDP for Italy in 2017 is equal to 13\%, a value above the average of the EU countries and the world economy as a whole. In terms of employees, the sector was responsible for almost 3.4 million jobs, equal to $15 \%$ of the total. In Italy, the importance of large hotel chains is much more limited than in other European states. Looking at the data for 2017, the hotels belonging to chains were almost 1,500, equal to 4.5 per cent, a significantly lower percentage compared to France $(21 \%)$ and Spain $(12 \%)$. In the context outlined, the Italian hotel companies are predominantly small and medium-size, contributing significantly to employment and producing a high added value (Eurostat, Structural Business Statistics, 2017; Banca d'Italia, 2019). Despite support programs at the EU and the national level, access to finance remains one of SME's key problems in some Member States.

Banking products represent the most significant financing source or SMEs, while the other instruments offered on the market, such as shares, debt securities and other financial instruments, are instead used in a residual manner. In the latest ECB report (2019), Italian SMEs reported a growing need for bank loans and credit lines, highlighting that the lack of adequate access to finance determines strong constraints on business development and, at the same time, increases the risk of financial distress.

Besides, current credit regulations amplify these problems by imposing stricter and more restrictive conditions for granting credit. This circumstance, therefore, determines a reduction in the volume of loans which, very often, results in a reduction in the supply of credit to SMEs.

In this regard, the literature has highlighted that information asymmetries (Stiglitz \& Weiss, 1981), lower information transparency, tax variable (Cohen et al., 2013), high transaction costs (Beck and de la Torre 2007) and 
irregular credit histories can significantly affect the flexibility of these firms, increasing credit constraints (Cressy \& Olofsson, 1997; Beck \& Demirguc-Kunt, 2006; Sensini, 2020).

In the context briefly outlined, financial choices play a fundamental role in favouring SMEs' survival and development (Chen et al., 2014).

In this regard, the literature has shown that the specific characteristics of the firm, of the reference market and other economic factors can determine different behaviours on the part of firms (Chalmers et al., 2020), also suggesting that analyzing firms belonging to the same sector may represent a crucial factor in avoiding the possible anomalies determined by the analysis of companies belonging to different sectors (Hall et al., 2004; Sensini L., 2017; Chen et al., 2019).

In this perspective, hotel companies have some typical features compared to companies operating in other sectors, which could significantly affect their financial behaviour.

In particular, on the one hand, the high fixed costs lead to a high financial requirement (Lee and Qu, 2011; Devesa and Esteban, 2011; Hua et al., 2012), which tends to be constant and independent of production volumes and sales (Bello and Sensini, 2020). On the other hand, the presence of high fixed assets can facilitate access to finance. These assets represent a guarantee for creditors and reduce information asymmetry problems and bankruptcy risks (Dalbor and Upneja, 2004; Tang and Jang, 2007; Sensini, 2016). Besides, the difficulties related to forecasting demand, the variability of costs associated with customer intermediation (direct and/or indirect channel), and the seasonality that often characterizes hotel companies lead to inconstant cash flow over time and greater volatility of profits (Elgonemy, 2002, Devesa e Esteban, 2011, Lee e Qu, 2011, Hua et al., 2012).

In this perspective, this paper aims to analyze the determinants of SMEs' capital structure in the hotel sector, using a sample of companies operating in Italy. The period analyzed includes a time horizon of 7 years and runs from 2010 to 2018 (inclusive)

Although the literature has extensively shown the differences in financial behaviour between SMEs and large firms (Berger \& Udell, 1998; Michaelas et al., 1999; López-Gracia \& Sogorb-Mira, 2008; Macan Bhaird \& Lucey, 2010; among others), few studies have focused on this topic in the context of hotel businesses (Sheel, A.,1994; Dalbor \& Upneja, 2004; Madan, 2007; Tang \& Jang, 2007; Karadeniz et al., 2009; Such et al., 2009; Devesa \& Esteban, 2011; Farcnik et al., 2015; Pacheco \& Tavares, 2017; Botta, 2018).

This research results can enrich the existing literature, providing further empirical evidence on hotel companies' financial behaviour in a specific economic context.

Furthermore, considering the period analyzed (2010-18), the constraints that characterize SMEs and the current health emergency (Covid-19), the results provide useful information to entrepreneurs and managers to adopt financial solutions compatible with the characteristics of their business (Graham and Harvey, 2001; Petersen and Rajan, 2002; Srinivas, 2005) and to national authorities to define any financial support policies (Bello and Sensini, 2020).

The paper is organized as follows. The next section presents the literature review and research hypotheses. The third illustrates the methodology and variables used, while the fourth presents the analysis of the results. The final section contains the concluding remarks.

\section{Literature Review and Research Hypotheses}

Starting from Modigliani and Miller $(1958,1963)$ seminal papers, the issue of the capital structure has progressively attracted many scholars who have developed different theories. Although initially, the literature has focused mainly on large companies (Harris \& Raviv, 1991; Rajan \& Zingales, 1995; among others), over time, many authors have shifted the attention to SMEs, suggesting these companies have specific characteristics that need to be adequately investigated. In this perspective, the results of empirical research referring to large enterprises cannot be generalized and accepted also regarding SMEs (Berger \& Udell, 1998; Mac \& Bhaird, 2010).

Following this approach, the adequate theories to explain the capital structure of SMEs are the trade-off theory (TO) and the pecking order theory (PO) (Watson and Wilson, 2002; Sogorb-Mira, 2008; Hovakimian and Li, 2011; Aybar-Arias et al., 2012; Serrasqueiro \& Maças Nunes, 2012; Chalmers et al., 2020).

According to the trade-off theory (TO), the capital structure is influenced by the fiscal variable, bankruptcy costs, and agency costs. This approach, assuming an optimal capital structure, suggests that companies prefer to use external financial resources until leverage reaches an optimal level (Jensen \& Meckling, 1976; Cassar \& Holmes, 2003). However, according to Myers (1984), the debt level is influenced by possible financial distress costs.

According to the pecking order theory (PO), on the other hand, the financing choices of companies are based on 
hierarchical order, based on the degree of information asymmetry between owners/managers and investors (Sensini, 2020). In this perspective, companies meet their financial needs by first using profits, then debt and, lastly, the issue of shares (Cosh \& Hughes, 1994; Vos et al., 2007).

Therefore, the more profitable firms will tend to finance investments with their own resources, while the less profitable firms will borrow or issue new shares to finance their investments (Myers, 1984; Rajan e Zingales, 1995).

The theoretical approach suggested by the two theories just mentioned can be useful to explain the financial behaviour of firms and therefore understand the financial choices of SMEs (Watson \& Wilson, 2002; Titman \& Tsyplakov, 2007; López-Gracia \& Sogorb-Mira 2008; Hovakimian \& Li, 2011; Aybar-Arias, 2012; Degryse et al., 2012).

Therefore, also based on the results that emerged in previous empirical studies (Aggarwal, 1981; Titman \& Wessels, 1988; Fama and French, 2002; Cassar \& Holmes, 2003; Abor, 2008; Frank \& Goyal, 2009; Sanchez \& Sensini, 2017), this research focuses on the relationship between debts (total, long-term and short-term) and the following main explanatory variables: profitability, assets tangibility, growth (calculated regarding assets and turnover), size and age.

The paper's research hypotheses are developed, trying to decline the suggestions of the two main theories mentioned to hotel SMEs' specificities.

\section{Profitability}

The trade-off theory suggests that the most profitable firms have a greater ability to attract external finance (Jang et al. 2008) and therefore prefer to use debt to exploit the benefits of the deduction of interest tax (Modigliani and Miller, 1963).

Conversely, the Pecking Order theory suggests that the most profitable companies prefer to finance investments following a hierarchical order favouring internal financial resources first.

Therefore, given the general reluctance of SMEs to favour the entry of external investors (Vos et al. 2007), profitable firms will use firstly operating profits (Myers, 1984; Myers \& Majluf, 1984) and, only if these funds are not sufficient, the debt (Van der Wijst \& Thurik 1993; Michaelas et al. 1999; Sogorb-Mira 2005; Degryse et al., 2012).

Therefore, in line with the Pecking Order theory, our research hypotheses are as follows:

$H 1$ - Profitability is negatively related to total debt (TD).

H1a - Profitability is negatively related to long-term debt (LTD).

H1b -Profitability is negatively related to short-term debt (STD)

Assets tangibility

Both theories, albeit with partially different motivations, suggest a positive relationship between assets tangibility and debt (Harris and Raviv, 1991; Jimenez et al., 2006; Abor and Biekpe, 2009).

In this regard, hotel companies generally have a high level of fixed assets used as collateral for creditors. However, at the same time, the strong volatility of revenues and the rigidity of the structure can increase business risk. Therefore, these firms have higher medium and long-term debt than short-term ones.

Therefore, our research hypotheses are as follows:

H2 - Assets tangibility is positively related to total debt (TD)

H2a - Assets tangibility is positively related to long-term debt (LTD)

H2a - Assets tangibility is negatively related to short-term debt (STD).

Growth

The growth can be related to increased activities and/or turnover (Michaelas et al., 1999; Poornima \& Manokaran, 2012).

In this regard, the trade-off theory suggests a negative relationship between growth and debt (Jensen, 1986; Elgonemy, 2002).

Conversely, the Pecking Order theory predicts a positive relationship between growth and debt. Some authors (Ramalho and Silva, 2013) have suggested that companies with high growth rates prefer to borrow. These companies do not have sufficient internal funds and want to avoid other investors' entry into the share capital. 
Therefore, based on the Pecking Order theory, our research hypotheses are as follows:

H3 - Growth is positively related to total debt (TD).

H3a - Growth is positively related to long-term debt (LTD).

$H 3 b$ - Growth is positively related to short-term debt (STD).

Size

Although with partially different motivations, both theories suggest a positive relationship between size and debt (Michaelas et al., 1999; Frank and Goyal, 2003; Fama and French, 2007). This positive relationship is also confirmed by some specific studies in the hotel sector (Devesa and Esteban, 2011; Serrasqueiro and Nunes, 2014).

However, the size's positive effect on debt also depends on the debts' maturity (Sanchez and Sensini, 2017). In this perspective, the small size often entails the obligatory recourse to short-term debt, while the larger size favours recourse to medium and long-term debt.

Therefore, our research hypotheses are as follows:

H4 - Size is positively related to total debt (TD).

$\mathrm{H} 4 \mathrm{a}$ - Size is positively related to long-term debt (LTD).

$H 4 b$ - Size is negatively related to short-term debt (STD).

Age

The trade-off theory predicts that older age increases a firm's reputation and allows for lower-cost borrowing, suggesting a positive relationship between age and debt.

Pecking Order Theory suggests that younger firms are more dependent on debt, while older firms rely on their ability to generate profits and are less dependent on debt (Michaelas et al., 1999; Mac an Bhaird and Lucey, 2010). However, the empirical results of this approach have often highlighted conflicting results.

Therefore, our research hypotheses are as follows:

H5 - Age is negatively related to total debt (TD).

H5a - Age is positively related to long-term debt (LTD).

H5b - Age is negatively related to short-term debt (STD).

The following table summarizes the assumptions made regarding each variable considered.

Table 1. Dependent and independent variables and expect sign

\begin{tabular}{|c|c|c|c|}
\hline Hypothesis & Independent Variables & Dependent Variables & Expected Sign \\
\hline $\mathrm{H} 1$ & Profitability & TD & - \\
\hline H1a & & LTD & - \\
\hline $\mathrm{H} 1 \mathrm{~b}$ & & STD & - \\
\hline $\mathrm{H} 2$ & Assets Tangibility & $\mathrm{TD}$ & + \\
\hline $\mathrm{H} 2 \mathrm{a}$ & & LTD & + \\
\hline $\mathrm{H} 2 \mathrm{~b}$ & & STD & - \\
\hline $\mathrm{H} 3$ & Growth & $\mathrm{TD}$ & + \\
\hline $\mathrm{H} 3 \mathrm{a}$ & & LTD & + \\
\hline $\mathrm{H} 3 \mathrm{~b}$ & & STD & + \\
\hline $\mathrm{H} 4$ & Size & $\mathrm{TD}$ & + \\
\hline $\mathrm{H} 4 \mathrm{a}$ & & LTD & + \\
\hline $\mathrm{H} 4 \mathrm{~b}$ & & STD & - \\
\hline H5 & Age & $\mathrm{TD}$ & - \\
\hline H5a & & LTD & + \\
\hline $\mathrm{H} 5 \mathrm{~b}$ & & STD & - \\
\hline
\end{tabular}

\section{Methodology and Variables}

This study focuses on the relationship between the main determinants of the capital structure and hotel SMEs' debt. 
The analysis's financial information was collected from the Bureau Van Dijk (BVD) AIDA database and covered a seven-year period, from 2010 to 2018 (inclusive).

To select the companies to be analyzed, we used the following criteria. First, the companies had to fall within the definition of SMEs provided by the European Commission. Secondly, the financial statements of the companies had to be available throughout the period analyzed. Thirdly, we excluded companies that were part of groups. Finally, to have a complete information panel, we excluded the companies for which it was impossible to calculate all the indicators considered for this analysis.

The final sample comprises 145 companies and is represented by small (73) and medium-sized (72) enterprises.

To assess the capital structure, this study uses quantitative analysis tools. Therefore, based on the financial statements' accounting information, we calculated the dependent and independent variables of interest. These variables are consistent with the previously formulated research hypotheses and with the main reference literature (Van der Wijst \& Thurik, 1993; Michaelas et al., 1999; Faulkender \& Petersen, 2006; Frank \& Goyal, 2009; Faulkender \& Petersen, 2006; Degryse et al., 2012; Sensini, 2020; among others).

All the dependent and independent variables are summarized in Table 2 and have been determined as better specified below.

Table 2. Dependent and independent variables

\begin{tabular}{lll}
\hline Dependent Variables & & \\
\hline TD & Total debt & Total Liabilities/Total Assets \\
MLD & Medium and long-term debt & Non-current Liabilities/Total Assets \\
STD & Short-term debt & Current Liabilities/Total Assets \\
\hline Independent Variables & & \\
\hline PROF & Profitability & EBIT/Total Assets \\
TAS & Tangibility Assets & Tangible Assets/Total Assets \\
AGR & Assets Growth & $\left(\right.$ Total Assets $_{\mathrm{i}, \mathrm{t}}-$ total Assets $\left._{\mathrm{i}, \mathrm{t}-1}\right) /$ Total $_{\text {Assets }}$ Ast-1 \\
TGR & Turnover Growth & $\left(\right.$ Turnover $_{\mathrm{i}, \mathrm{t}}-$ Turnover $\left._{\mathrm{i}, \mathrm{t}-1}\right) /$ Turnover $_{\mathrm{i}, \mathrm{t}-1}$ \\
SIZE & Size & Number of years in activity \\
AGE & Firm age & Year of data - Year of foundation \\
\hline
\end{tabular}

Table 3 shows the trend of the variables analyzed regarding three periods [(2010-2013 (III), 2014-2017 (II); 2018 (I)].

Table 3. Variables (Mean and Standard Deviation)

\begin{tabular}{lllll}
\hline Variables & I & II & III & SD \\
\hline TD & 0.59 & 0.61 & 0.63 & 0.28 \\
LTD & 0.32 & 0.35 & 0.35 & 0.24 \\
STD & 0.26 & 0.32 & 0.31 & 0.29 \\
PROF (\%) & 4.06 & 3.86 & 3.11 & 5.77 \\
TAS & 0.73 & 0.73 & 0.68 & 7.22 \\
AGR (\%) & 1.22 & 1.42 & 0.14 & 11.07 \\
TGR (\%) & 3.19 & 1.15 & 0.04 & 12.72 \\
SIZE & 9.94 & 9.91 & 9.45 & 1.14 \\
AGE & 29.16 & 27.22 & 25.19 & 14.27 \\
\hline
\end{tabular}

As can be seen from the table, in the phase immediately following the 2008 crisis (III), companies show a higher level of debt, lower profitability and lower growth than in the other periods (I and II).

Table 4 shows the correlation coefficients between the independent variables. 
Table 4. Correlation matrix (independent variables)

\begin{tabular}{llllll}
\hline Variables & PROF & TAS & AGR & TGR & SIZE \\
\hline PROF & - & $-0.142^{* *}$ & -0.019 & $0.274^{* *}$ & $-0.254^{* *}$ \\
TAS & & - & $-0.086^{*}$ & 0.042 & $0.093^{*}$ \\
AGR & & - & -0.016 & 0.014 & $-0.188^{* *}$ \\
TGR & & & - & 0.007 & -0.028 \\
SIZE & & & & -0.012 \\
AGE & & & & $-215^{* *}$ \\
\hline
\end{tabular}

Note. Stars indicate statistical significance respectively at: $* * * 1 \% ; * * 5 \% ; * 10 \%$.

As is evident, the correlation coefficients between the independent variables do not present significant collinearity problems.

To test the research hypotheses, we applied a panel data methodology, using the least squares (POLS) and the fixed effects (FEM) models, developing the following regressions for all dependent variables (TD, LTD and STD):

$$
Y_{i t}=\beta_{1}+\beta_{2} P E R F_{i t_{i}}+\beta_{3} T A S_{i t}+\beta_{4} A G R_{i t}+\beta_{5} T G R_{i t}+\beta_{6} S I Z E_{i t}+\beta_{6} A G E_{i t}+\epsilon_{i t}
$$

Where Yit is a dependent variable, $\beta$ is the coefficient to estimate, Xit is the independent variable, and cit is the error describing the non-explained effects on Yit.

\section{Results and Discussion}

As a preliminary, we developed the regressions using the least squares (POLS) and the fixed effects (FEM) models, to identify the model with the greatest explanatory capacity.

The results are shown in Table 5 .

Table 5. POLS and FEM

\begin{tabular}{|c|c|c|c|c|c|c|}
\hline \multirow{2}{*}{$\begin{array}{l}\text { Model } \\
\text { Variables }\end{array}$} & \multicolumn{3}{|l|}{ POLS } & \multicolumn{3}{|l|}{ FEM } \\
\hline & TD & LTD & STD & TD & LTD & STD \\
\hline PROF & $-0.992 *$ & -0.651 & -0.594 & $-1.029 * * *$ & $-0.944 *$ & -0.082 \\
\hline TAS & $-0.156^{* *}$ & $0.294 * * *$ & $-0.452 * * *$ & 0.059 & $0.278^{*}$ & -0.157 \\
\hline AGR & 0.002 & 0.009 & -0.008 & 0.002 & 0.002 & 0.008 \\
\hline TGR & 0.028 & 0.008 & 0.015 & $0.034 * *$ & 0.012 & 0.018 \\
\hline SIZE & 0.016 & 0.012 & -0.024 & 0.011 & $-0.118 * *$ & $-0.082 *$ \\
\hline AGE & -0.003 & 0.014 & -0.006 & $-0.009 * *$ & -0.006 & 0.012 \\
\hline
\end{tabular}

To check which model is more efficient, we performed the Wald test, which suggests that the FEM model is more significant (TD: 18.788***; LTD: 7.477***; STD: 14.026***).

Therefore, we applied the FEM model to the variables that were significant in the previous estimate. The results are shown in Table 6.

Table 6. Regression FEM

\begin{tabular}{llll}
\hline Variables & TD & LTD & STD \\
\hline PROF & $-1.1287^{* * *}$ & $-0.7377^{* *}$ & NR \\
TAS & NR & $0.0371^{* * *}$ & NR \\
AGR & NR & NR & NR \\
TGR & $0.0379^{* * *}$ & $\mathrm{NR}$ & $\mathrm{NR}$ \\
SIZE & $\mathrm{NR}$ & $0.0856^{*}$ & $-0.343^{*}$ \\
AGE & $-0.321^{*}$ & $\mathrm{NR}$ & $\mathrm{NR}$ \\
$\mathrm{R}^{2}$ & 0.88 & 0.71 & 0.78 \\
$\mathrm{~F}$ & 58.23 & 18.16 & 25.94 \\
\hline
\end{tabular}

Stars indicate statistical significance respectively at: ***1\%; $* * 5 \%$; $* 10 \%$; NR: Not Relevant. 
Profitability shows a negative relationship with total debt and with medium and long-term debt. Conversely, the relationship with short-term debt is not relevant. The results suggest that the most profitable SMEs prefer to use profits, rather than debt, to finance investments.

Empirical findings are consistent with the pecking order theory (Van der Wijst \& Thurik 1993; Michaelas et al. 1999; Sogorb-Mira 2005; Degryse et al. 2012) and with previous studies that investigated hotel businesses (Ajanthan, 2013; Matias et al., 2018).

The relationship between the tangibility of assets and the different debt types is significant and statistically significant only for medium and long-term debt, confirming the H2b hypothesis. These results suggest that firms with a high level of tangible fixed assets tend to have greater ease in accessing medium- and long-term financing, as they can provide greater guarantees to creditors and therefore reduce adverse selection problems (Stiglitz and Weiss, 1986).

These results are consistent with both theories analyzed and with previous empirical research in the hotel sector (Dalbor and Upneja; 2004, Tang and Jang, 2007; Serrasqueiro and Nunes, 2014; Matias et al., 2018). However, other authors (Devesa and Esteban, 2011) have suggested that fixed assets' rapid obsolescence results in an opposite relationship.

The results relating to growth mainly highlight non-significant relationships. However, the growth rate of turnover is significantly correlated with total debt. These findings suggest that SMEs with higher revenue growth have a better chance of financing growth with debt. Empirical findings are partially in line with pecking order theory and previous studies on hotel businesses (Dalbor and Upneja, 2004; Tang and Jang, 2007) but diverge from other research (Serrasqueiro and Nunes, 2014).

The size shows an insignificant relationship with total debt, a positive and significant relationship with medium and long-term debt and a negative and significant relationship with short-term debt.

Such positive and meaningful relationships are stronger in medium-sized companies, while they decrease significantly in smaller companies. Overall, the results show SMEs' general tendency to prefer short-term debt to medium and long-term debt, confirming the financial constraints that characterize these companies (Cressy and Olofsson, 1997; Beck and Demirguc-Kunt, 2006; Banerjee, 2014; Sensini, 2020).

Finally, age has a significant and negative relationship with total debt, while it is not relevant in other cases. These results are consistent with the pecking order theory and previous studies on hotel businesses (Pacheco and Tavarez, 2017; Matias et al., 2018).

Empirical findings suggest that longer-lived firms, especially when profitable, have greater self-financing capabilities and prefer to use internal resources rather than bank financing (Michaelas et al., 1999; Sensini, 2017).

Table 7 summarizes the results of the analysis concerning the research hypotheses.

Table 7. Dependent and independent variables and expect sign

\begin{tabular}{lllll}
\hline Hypothesis & Independent Variables & Dependent Variables & Expected Sign & Results \\
\hline H1 & & TD & - & - \\
H1a & Profitability & LTD & - & - \\
H1b & & STD & - & NR \\
H2 & & TD & + & NR \\
H2a & Tangibility Assets & LTD & + & + \\
H2b & & STD & - & NR \\
H3 & & TD & + & + \\
H3a & Growth & LTD & + & NR \\
H3b & & STD & + & NR \\
H4 & & TD & + & NR \\
H4a & Size & LTD & + & + \\
H4b & & STD & - & - \\
H5 & & TD & - & - \\
H5a & Age & LTD & + & NR \\
H5b & & STD & - & NR \\
\hline
\end{tabular}




\section{Concluding Remarks}

This paper analyses the determinants of hotel SMEs' capital structure, using the theoretical reference framework and the main indicators suggested by the Trade-off and the Pecking Order theories.

The financial information was collected from the AIDA database (Bureau Van Dijk) and covered seven years (from 2010 to 2018 inclusive). Based on the selection criteria indicated in paragraph 3, we have identified a sample consisting of 145 Italian hotel companies, all falling into SMEs' category based on the European Commission's criteria.

To assess the capital structure, we used quantitative analysis tools. Based on the accounting information, we calculated the dependent variables (Total Debt, Long-Term Debt and Short-Term Debt) and the independent ones (Profitability, Assets Tangibility, Growth, Size and Age).

As a preliminary step, to choose the model with the greatest explanatory capacity, we used a panel data methodology, developing the regressions on the least squares (POLS) and the fixed effects (FEM) models.

In this regard, the fixed effects model (FEM) has shown a greater explanatory capacity, and therefore we tested our hypotheses using this model.

The results suggest that the most profitable SMEs prefer to use profits, rather than debt, to finance investments.

The assets tangibility is statistically significant only for medium and long-term debt, suggesting that firms with a high level of tangible fixed assets tend to have greater ease in accessing financing. They can provide greater guarantees to creditors and therefore reduce adverse selection problems and asymmetry information.

The results relating to growth mainly highlight non-significant relationships. However, the significant correlation between revenue growth rate and total debt suggests that SMEs with higher revenue growth have a better chance of financing growth with debt.

The size shows a positive and significant relationship with medium and long-term debt and a significant and negative relationship with short-term debt, confirming SMEs' general tendency to prefer short-term debt over debt medium and long term.

Finally, age has a significant and negative relationship with total debt, suggesting that young companies have greater difficulties accessing credit.

The results of this research can enrich the existing literature, providing further empirical evidence on the financial behaviour of hotel companies in a specific economic context. Furthermore, considering the constraints that characterize SMEs, the results provide useful information for entrepreneurs and managers to adopt financial solutions compatible with their business characteristics. Finally, in consideration of the current health emergency in progress (Covid-19), the results can support the national authorities in defining any financial support policies appropriate to hotel companies' specificities.

\section{Authorship Contribution Statement}

Mueller A.: Data curation, Data Analysis, Results and Discussion, Concluding Remarks.

Sensini L.: Conceptualization, Methodology, Data Analysis, Results and Discussion; Concluding Remarks.

\section{References}

Abor, J. (2008). Agency theoretic determinants of debt level: evidence from Ghana. Review of Accounting and Finance, 7(2), 183-92.

Abor, J., \& Biekpe, N. (2009). How do we explain the capital structure of SMEs in sub-Saharan Africa? Evidence from Ghana. Journal of Economic Studies, 36(1), 83-97.

Aggarwal, R. (1981). International differences in capital structure norms: an empirical study of large European companies. Management International Review, 21(1), 75-88.

Ajanthan, A. (2013), Determinants of Capital Structure: Evidence from Hotel and Restaurant Companies in Sri Lanka. International Journal of Scientific and Research Publications, 3(6), 1-8.

Aybar-Arias, C., Casino-Martínez, A., \& López-Gracia, J. (2012). On the adjustment speed of SMEs to their optimal capital structure. Small Business Economics, 39(4), 977-996.

Banca d'Italia. (2019). Turismo in Italia: numeri e potenziale sviluppo, Questioni di economia e finanza (occasional paper), n. 505.

Banerjee, R. N. (2014). SMEs, financial constraints and growth, BIS Working Papers No. 475. 
Beck T., \& Demirguc-Kunt, A. (2006). Small and medium-size enterprises: Access to finance as a growth constraint. Journal of Banking and Finance, 30(11), 2931-2943.

Beck, T., \& Torre, A. (2007). The basic analytics of access to financial services. Financial Market Institutions \& Instruments, 16(2), 79-117.

Bello, C., \& Sensini, L. (2020). Financing Decisions in the Hotel Industry, International Journal of Academic Research in Accounting. Finance and Management Sciences, 10(2), 9-14.

Berger, N. A., \& Udell, F. G. (1998). The economics of small business finance: the roles of private equity and debt markets in the financial growth cycle. Journal of Banking \& Finance, 22(6-8), 613-673.

Botta. (2019). Financing Decisions and Performance of Italian SMEs in the Hotel Industry. Cornell Hospitality Quarterly, 60(4), 335-354.

Cassar, G., \& Holmes, S. (2003). Capital structure and financing of SMEs: Australian evidence. Accounting and Finance, 43(2), 123-147.

Chalmers, D. K., Della Porta, M., \& Sensini, L. (2020). Export Intensity and Leverage: an empirical analysis of Spanish SMEs. International Journal of Economics and Financial Issues, 10(5), 382-386.

Chen, J., Hughes, C., \& Sensini, L. (2014). Credit risk measurement of SMEs, International Conference on Economics Finance and Risk, 139-163.

Chen, Y., Durand, F., Mannetta, E. W., \& Shan, A. (2019). Capital Structure Determinants in French SME's: empirical findings.

Cohen, W., Sanchez, J. A., \& Sensini, L. (2013). The relevance of tax information in financial statement. International Conference on Accounting Finance and Risk Management Perspective (pp. 141-166).

Cosh, A. D., \& Hughes, A. (1994), Size, financial structure and profitability. In Hughes A., Storey D. J. (Eds.), Finance and the Small Firm (pp. 18-63). Routledge, London

Cressy, R., \& Olofsson, C. (1997). The financial conditions for Swedish SMEs: Survey and research. Agenda Small Business Economics, 9(2), 179-192.

Dalbor, M., \& Upneja, A. (2004), The investment opportunity set and the long-term debt decision of U.S. lodging firms. Journal of Hospitality and Tourism Research, 28(3), 346-355.

Degryse, H., Goeij, P., \& Kappert, P. (2012), The impact of firm and industry characteristics on small firms' capital structure. Small Business Economics, 38, 431-447.

Devesa, M., \& Esteban, L. (2011), Spanish hotel industry: indebtedness determinants. Applied Economics, 43, 4227-4238.

Elgonemy, A. (2002). Debt-financing alternatives: refinancing and restructuring in the lodging industry. The Cornell Hotel and Restaurant Administration Quarterly, 43(3), 7-21.

European Central Bank. (2019). Survey on the access to finance of enterprises (SAFE).

European Commission. (2020). An SME Strategy for a sustainable and digital Europe.

Fama, E., \& French, K. (2002). Testing trade-off and pecking order predictions about dividends and debt. The Review of Financial Studies, 15(1), 1-33.

Fama, E., \& French, K. (2007), The anatomy of value and growth stock returns. Financial Analysts Journal, 63(6), 44-54.

Farcnik, D., Kuscer, K., \& Trobec, D. (2015). Indebtedness of the tourism sector in Mediterranean countries. Tourism Economics, 21(1), 141-157.

Faulkender, M., \& Petersen, M. A. (2006), Does the source of capital affect capital structure? Review of Financial Studies, 19(1), 45-79.

Frank, M., \& Goyal, V. (2003). Testing the pecking order theory of capital structure. Journal of Financial Economics, 67(2), 217-248.

Frank, M., \& Goyal, V. (2009). Capital structure decisions: which factors are reliably important? Financial Management, 38, 1-37.

European Central Bank. (2019). Survey on the access to finance of enterprises (SAFE).

Graham, J. R., \& Harvey, C. R. (2001). The theory and practices of corporate finance: evidence from the field. 
Journal of Financial Economics, 60, 187-243.

Hall, G., Hutchinson, P., \& Michaelas, N. (2004), Determinants of the Capital Structure of European SMEs. Journal of Business Finance and Accounting, 31(5/6), 711-728.

Harris, M., \& Raviv, A. (1991). The theory of capital structure. The Journal of Finance, 46(1), 297-355.

Hovakimian, A., \& Li, G. (2011). In search of conclusive evidence: how to test for adjustment to target capital structure. Journal of Corporate Finance, 17(1), 33-44.

Hua, N., Nusair, K., Upneja, A. (2012), Financial characteristics and outperformance, evidence of a contemporary framework from the US lodging industry. International Journal of Contemporary Hospitality Management, 24, 574-593.

Jang, S., Tang C. H., \& Chen, M. (2008), Financing behaviors of hotel companies. International Journal of Hospitality Management, 27(3), 478-487.

Jensen M. C., Meckling, W. H. (1976). Theory of the firm: Managerial behavior, agency costs and ownership structure. Journal of Financial Economics, 3(4), 305-360.

Jensen, M. (1986). Agency costs of free cash flow, corporate finance, and takeovers. The American Economic Review, 76(2), 323-329.

Jimenez, G., Salas, V., \& Saurina, J. (2006). Determinants of collateral. Journal of Financial Economics, 81, 255281.

Karadeniz, E., Kandir, S., \& Balcilar, M. (2009). Determinants of capital structure: evidence from Turkish lodging companies. International Journal of Contemporary Hospitality Management, 21(5), 594-609.

Lee, S., Qu, X. (2011). An examination of the curvilinear relationship between capital intensity and firm performance for publicly traded US hotels and restaurants. International Journal of Contemporary Hospitality Management, 23, 862-880.

López-Gracia, J., \& Sogorb-Mira, F. (2008). Testing trade-off and pecking order theories financing SMEs. Small Business Economics, 31(2), 117-136.

Mac an Bhaird, C., \& Lucey, B. (2010). Determinants of capital structure in Irish SMEs. Small business economics, $35(3), 357-375$.

Macchiavelli, A. (2001). Tourist destinations as integrated systems. Tourism Review, 56(3/4), 6-11.

Madan, K. (2007). An analysis of the debt-equity structure of leading hotel chains in India. International Journal of Contemporary Hospitality Management, 19(5), 397-414.

Matias, F., Salsa, L., \& Afonso, C. M. (2018). Capital structure of Portuguese hotel firms: a structural equation $\begin{array}{lllll}\text { modelling approach. Tourism \& Management } & \text { Studies, } & \text { 14(SI1), }\end{array}$ https://doi.org/10.18089/tms.2018.14SI108

Michaelas, N., Chittenden, F., \& Poutzioris, P. (1999). Financial policy and capital structure choice in U.K. SMEs: Empirical evidence from company panel data. Small Business Economics, 12(2), 113-130.

Myers, C. (1984). The capital structure puzzle. The Journal of Finance, 39(3), 574-592.

Modigliani, F., Miller, M. H. (1958). The cost of capital, corporation finance and the theory of investment. American Economic Review, 48(3), 261-297.

Modigliani, F., \& Miller, M. (1963). Corporate income taxes and the cost of capital: a correction. American Economic Review, 53(3), 433-443.

Pacheco, L., \& Tavares, F. (2017). Capital structure determinants of hospitality sector SMEs. Tourism Economics, 2(1), 113-132.

Petersen, M. A., \& Rajan, R. G. (2002). Does distance still matter? The information revolution in small business lending. Journal of Finance, 57(6), 2533-2570.

Poornima, S., \& Manokaran, G. (2012). Capital structure analysis of asset financing services industry in India. Biz N Bytes: Journal of Applied Management \& Computer Science, 1, 1-19.

Rajan, R., \& Zingales, L. (1995). What do we know about capital structure? Some evidence from international data. Journal of Finance, 50, 1421-1460.

Sanchez, J. A., \& Sensini, L. (2017). Small Firms and Demand for Credit. Evidence from Europe. ICAFR, 237- 
262.

Sensini, L. (2016). An Empirical Analysis of Financially Distressed Italian Companies. International Business Research, 9(10), 75-85. https://doi.org/10.5539/ibr.v9n10p75

Sensini, L. (2017). Capital Structure Determinants in Italian SME's: An Empirical Study. ICAFR, 124-144.

Sensini, L. (2020). Factors Driving Capital Structure of Italian SME’s. International Business Management, 14(7), 217-225.

Serrasqueiro, Z., Nunes, M. P. (2014). Financing behavior of Portuguese SMEs in hotel industry. International Journal of Hospitality Management, 43, 98-107.

Sheel, A. (1994). Determinants of capital structure choice and empirics on leverage behaviour: a comparative analysis of hotel and manufacturing firms. Hospitality Research Journal, 17(3), 3-16.

Sogorb, M. F. (2005). How SME uniqueness affects capital structure: Evidence from a 1994-1998 Spanish data panel. Small Business Economics, 25(5), 447-457.

Srinivas, Y. (2005). Bank Finance to SME sector- Issues and Perspectives. The Chartered Accountant, 54, 436439.

Stiglitz, J. E., \& Weiss, A. (1981). Credit rationing in markets with imperfect information. American Economic Review, 71(3), 393-410.

Such, M., Parte, L., \& Garre, A. (2009). The financial structure of the Spanish hotel industry: evidence from cluster analysis. Tourism Economics, 15(1), 121-138.

Tang, C. H., \& Jang, S., (2007). Revisit to the determinants of capital structure: a comparison between lodging firms and software firms. International Journal of Hospitality Management, 26, 175-187.

Van der Wijst, N., \& Thurik, R. (1993). Determinants of small firm debt ratios: An analysis of retail panel data. Small Business Economics, 5, 55-65.

Vos, E., Jia-Yuh, A., Carter, S., \& Tagg, S. (2007). The happy story of small business financing. Journal of Banking and Finance, 31, 2648-2672.

Wang, M. C. (2015). Value relevance of Tobin's Q and corporate governance for the Taiwanese tourism industry. Journal of Business Ethics, 130(1), 223-230.

Watson, R., \& Wilson, N. (2002). Small and medium size enterprise financing: a note on some of the empirical implications of a pecking order. Journal of Business Finance and Accounting, 29(3/4), 557-579.

Weiermair, K. (2006). Product improvement or innovation: what is the key to success in tourism? OECD (Ed.), Innovation and Growth in Tourism (pp. 53-67)

WTCC. (2018). Travel \& Tourism: Economic Impact 2018 - Italy. London.

\section{Copyrights}

Copyright for this article is retained by the author(s), with first publication rights granted to the journal.

This is an open-access article distributed under the terms and conditions of the Creative Commons Attribution license (http://creativecommons.org/licenses/by/4.0/). 